SRNL-STI-2009-00286

Revision 0

\title{
SALTSTONE 4QCY08 TCLP RESULTS
}

\section{A.D. Cozzi}

July 2009

Environmental and Chemical Process Technology Savannah River National Laboratory Aiken, SC 29808

This document was prepared in conjunction with work accomplished under Contract No. DE-AC09-08SR22470 with the U.S. Department of Energy.

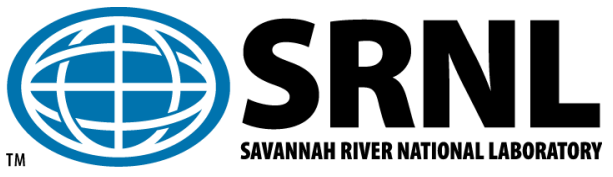


SRNL-STI-2009-00286

Revision 0

\section{DISCLAIMER}

This work was prepared under an agreement with and funded by the U.S. Government. Neither the U.S. Government or its employees, nor any of its contractors, subcontractors or their employees, makes any express or implied: 1 . warranty or assumes any legal liability for the accuracy, completeness, or for the use or results of such use of any information, product, or process disclosed; or 2. representation that such use or results of such use would not infringe privately owned rights; or 3. endorsement or recommendation of any specifically identified commercial product, process, or service. Any views and opinions of authors expressed in this work do not necessarily state or reflect those of the United States Government, or its contractors, or subcontractors.

This document was prepared in conjunction with work accomplished under Contract No. DE-AC09-08SR22470 with the U.S. Department of Energy. 
SRNL-STI-2009-00286

Revision 0

Keywords: saltstone, TCLP

Retention: permanent

\section{SALTSTONE 4QCY08 TCLP RESULTS}

\section{A.D. Cozzi}

July 2009

Environmental and Chemical Process Technology Savannah River National Laboratory Aiken, SC 29808

This document was prepared in conjunction with work accomplished under Contract No. DE-AC09-08SR22470 with the U.S. Department of Energy. 


\section{REVIEWS AND APPROVALS}

\section{AUTHORS:}

A.D. Cozzi, Engineering Process Development

Date

\section{TECHNICAL REVIEWER:}

R.E. Eibling, Engineering Process Development

Date

\section{APPROVERS}




\section{EXECUTIVE SUMMARY}

A Saltstone waste form was prepared in the Savannah River National Laboratory from a Tank $50 \mathrm{H}$ sample and Z-Area premix material for the fourth quarter of calendar year 2008 (4QCY08). After the prescribed 28 day cure, samples of the saltstone were collected, and the waste form was shown to meet the South Carolina Hazardous Waste Management Regulations (SCHWMR) R.61-79.261.24 and R.6179.268.48(a) requirements for a nonhazardous waste form with respect to RCRA metals and underlying hazardous constituents. These analyses met all quality assurance specifications of USEPA SW-846. 


\section{TABLE OF CONTENTS}

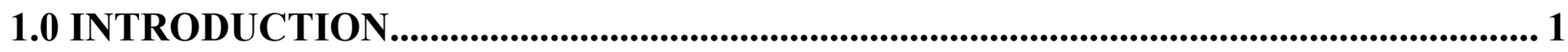

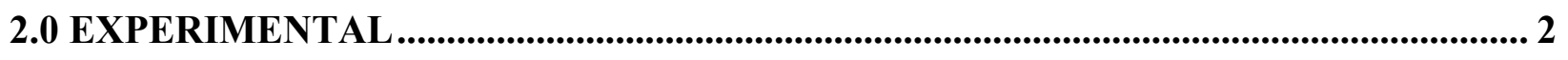

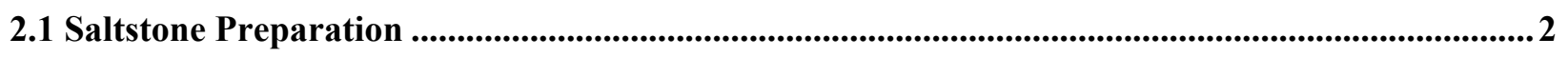

2.2 Saltstone Testing ...................................................................................................................................................... 5

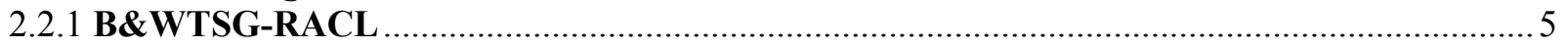

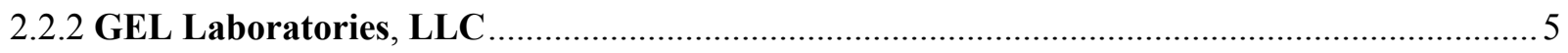

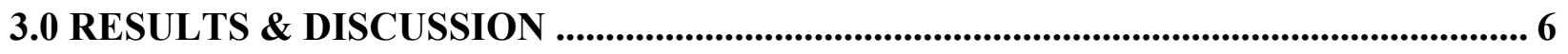

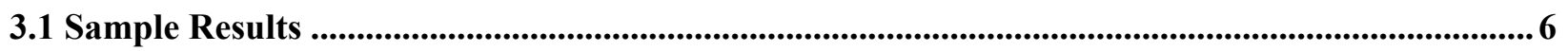

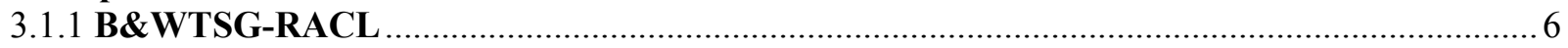

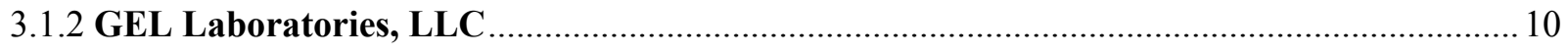

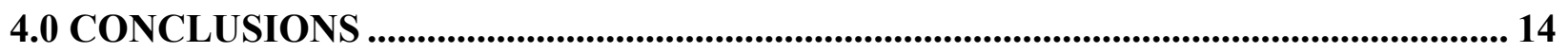

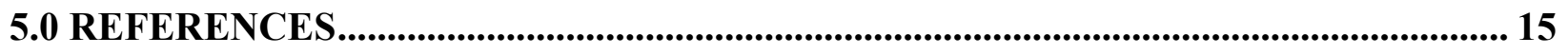




\section{LIST OF TABLES}

Table 1. Sample Results of TCLP Metals from Tank 50 WAC Analysis................................................. 3

Table 2. Customer Recommended Values for Preparation of TCLP Sample ............................................. 3

Table 3. TCLP Leachates RCRA Metal Concentrations, DLs, and QLs ............................................... 6

Table 4. Saltstone TCLP Results and Corresponding Regulatory Limits.............................................. 7

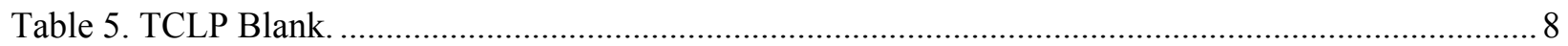

Table 6. RCRA Metal Laboratory Control Sample ……....................................................................... 9

Table 7. TCLP Leachates RCRA Metal Matrix Spike and Duplicate Results........................................ 10

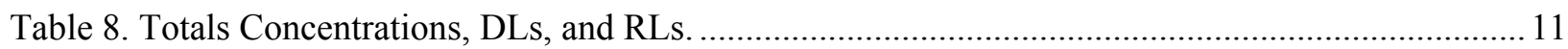

Table 9. Saltstone Totals Results and Corresponding Regulatory Limits.............................................. 11

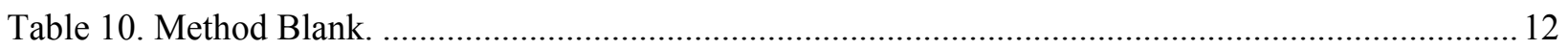

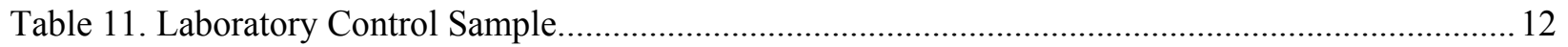

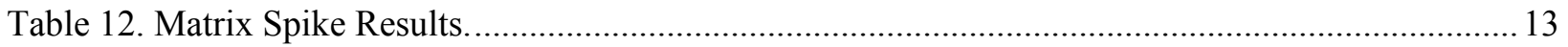


SRNL-STI-2009-00286

Revision 0

\section{LIST OF FIGURES}

Figure 1. Flowchart of saltstone sample preparation and analysis........................................................ 2

Figure 2. Data sheet for the saltstone mixes used to prepare samples for TCLP ..................................... 4 


\section{LIST OF ACRONYMS}

\begin{tabular}{|l|l|}
\hline B\&WTSG-RACL & $\begin{array}{l}\text { B \& W Technical Services Group-Radioisotope and Analytical Chemistry } \\
\text { Laboratory }\end{array}$ \\
\hline CVAA & Cold Vapor Atomic Absorption \\
\hline DL & Detection Limit \\
\hline DSS-HT & Decontaminated Salt Solution Hold Tank \\
\hline ESS-WP & Environmental Services Section - Waste Programs \\
\hline ETP & Effluent Treatment Project \\
\hline ICP-MS & Inductively Coupled Plasma - Mass Spectrometer \\
\hline ISWLF & Industrial Solid Waste Landfill \\
\hline LCS & Laboratory Control Sample \\
\hline MCL & Maximum Contaminant Level \\
\hline MCU & Modular Caustic Side Solvent Extraction Unit \\
\hline MS & Matrix Spike \\
\hline MSD & Matrix Spike Duplicate \\
\hline QL & Quantitation Limit \\
\hline RCRA & Resource Conservation and Recovery Act \\
\hline RL & Reporting Limit \\
\hline RPD & Relative Percent Differences \\
\hline SCDHEC & South Carolina Department of Health and Environmental Control \\
\hline SCHWMR & South Carolina Hazardous Waste Management Regulations \\
\hline SDF & Saltstone Disposal Facility \\
\hline SDG & Sample Delivery Group \\
\hline SPF & Saltstone Production Facility \\
\hline SRNL & Savannah River National Laboratory \\
\hline TCLP & Toxic Characteristic Leaching Procedure \\
\hline UHC & Underlying Hazardous Constituent \\
\hline UTS & Universal Treatment Standards \\
\hline
\end{tabular}




\subsection{Introduction}

The Saltstone Production Facility (SPF) receives waste from Tank $50 \mathrm{H}$ for treatment. In the fourth quarter of the 2008 calendar year (4QCY08), Tank 50 accepted transfers of approximately $15 \mathrm{kgal}$ from the Effluent Treatment Project (ETP) waste, approximately $12 \mathrm{kgal}$ from Tank 710 - the H-Canyon General Purpose Evaporator, approximately $5 \mathrm{kgal}$ from the H-Canyon Super Kukla campaign, and approximately 34 kgal from the Modular Caustic Side Solvent Extraction Unit (MCU) Decontaminated Salt Solution Hold Tank (DSS-HT).

The Saltstone Grout Sampling plan provides the South Carolina Department of Health and Environmental Control (SCDHEC) with the chemical and physical characterization strategy for the salt solution which is to be disposed of in the Z-Area Solid Waste Landfill (ISWLF). ${ }^{1}$ During operation, samples were collected from Tank $50 \mathrm{H}$ and grout samples prepared to determine the non-hazardous nature of the grout to meet the requirements of the South Carolina Hazardous Waste Management Regulations (SCHWMR) R.6179.261.24(b) and R.61-79.268.48(a).

SRNL was asked to prepare saltstone from a sample of Tank 50H obtained October 29, 2008 during 4QCY08 to determine the non-hazardous nature of the grout. The samples were cured and shipped to Babcock \& Wilcox Technical Services Group-Radioisotope and Analytical Chemistry Laboratory (B\&WTSG-RACL) to perform the Toxic Characteristic Leaching Procedure (TCLP) ${ }^{2}$ and subsequent extract analysis on saltstone samples for the analytes required for the quarterly analysis saltstone sample. In addition to the eight toxic metals - arsenic, barium, cadmium, chromium, mercury, lead, selenium and silver - analytes included the underlying hazardous constituents (UHC) antimony, beryllium, nickel, and thallium which could not be eliminated from analysis by process knowledge. ${ }^{3}$ B\&WTSG-RACL provided subsamples to GEL Laboratories, LLC for analysis for the UHCs benzene, phenols and total and amenable cyanide. 


\subsection{Experimental}

This section is a summary of the approach taken to prepare and characterize the saltstone samples. The saltstone sample preparation was performed at SRNL. Saltstone sample characterization was performed at both B\&WTSG-RACL facility in Lynchburg, Virginia and the GEL laboratory facility in Charleston, South Carolina. Figure 1 is a flowchart of the steps taken to prepare and characterize the saltstone samples.

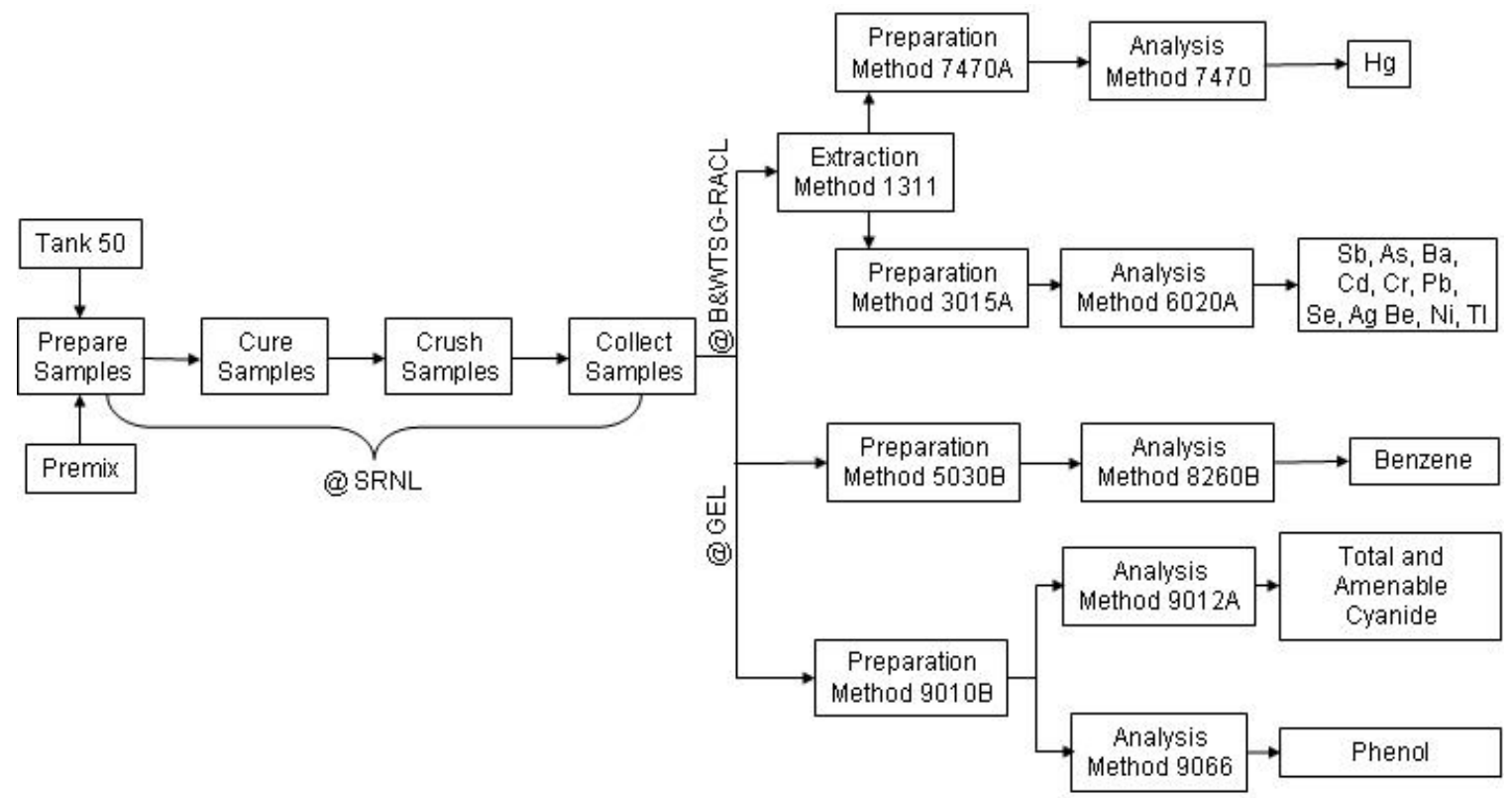

Figure 1. Flowchart of saltstone sample preparation and analysis.

\subsection{Saltstone Preparation}

Saltstone preparation was performed at SRNL. The weight percent solids data used for the TCLP sample was taken from the quarterly Waste Acceptance Criteria (WAC) analyses performed on Tank 50. ${ }^{4}$ Table 1 lists the concentration of TCLP metals of interest in the salt solution from the WAC analysis for the sample. Complete analysis of the salt solution used is in Reference 4. Table 2 contains the parameters used to prepare the TCLP sample. It should be noted that no Saltstone was process in 4QCY09 and the operating parameters used were from previous operations.

Saltstone samples for TCLP were prepared with the Tank $50 \mathrm{H}$ blended salt solution and a premix of cement, slag, and fly ash. Figure 1 shows the formulation used to prepare these samples. The salt solution, admixtures and premix materials were combined in a blender and mixed at low speed for one minute, inspected for incorporation of the premix, and then mixed at high speed for an additional two minutes. After the saltstone slurry was mixed, it was cast into a polyethylene zip top bag. The bag was laid flat and the air was expelled prior to sealing. The sample was cured flat in a polypropylene bag to facilitate the size reduction step needed to conform to the particle size requirements of the TCLP method.

After curing for not less than 28 days ${ }^{*}-57$ days for the $4 \mathrm{Q} 08$ sample, the saltstone was removed from the container and a portion of the saltstone was crushed to particles less than 0.9 centimeters $(3 / 8$ inch $)$ as prescribed by Section 7.13 of the TCLP method. ${ }^{2}$ The crushed saltstone was packaged into containers provided by Environmental Services Section - Waste Programs (ESS-WP). After the saltstone has been crushed, sieved and packaged, the sample is deemed "collected." ESS-WP retrieved the samples from SRNL and transported them to B\&WTSG-RACL for extraction and analysis. B\&WTSG-RACL

\footnotetext{
${ }^{*}$ Samples are considered ready for analysis after 28 days. Samples are not crushed until shipment has been scheduled.
} 
repackaged 9-10 grams of each of the four samples and shipped the samples to GEL Laboratories to perform totals analysis for the UHCs benzene, phenol and total and amenable cyanide.

Table 1. Sample Results of TCLP Metals from Tank 50 WAC Analysis.

\begin{tabular}{|c||c|c||}
\hline- & $\begin{array}{c}\text { Sample Results } \\
(\mathbf{m g} / \mathbf{L})^{\mathbf{4}}\end{array}$ & $\begin{array}{c}\text { Regulatory Limits } \\
(\mathbf{m g} / \mathbf{L})\end{array}$ \\
\hline- & $\mathbf{4 Q 0 8}$ & Toxicity $^{\mathbf{a}}$ \\
\hline $\mathbf{A s}$ & $<0.114$ & 5 \\
\hline $\mathbf{B a}$ & 0.602 & 100 \\
\hline $\mathbf{C d}$ & $<0.213$ & 1 \\
\hline $\mathbf{C r}$ & 38.4 & 5 \\
\hline $\mathbf{P b}$ & 0.538 & 5 \\
\hline $\mathbf{H g}$ & 12.6 & 0.2 \\
\hline $\mathbf{S e}$ & $<0.228$ & 1 \\
\hline $\mathbf{A g}$ & $<0.576$ & 5 \\
\hline-- & -- & $\mathbf{U H C}$ \\
\hline $\mathbf{S b}$ & $<3.69$ & 1.15 \\
\hline $\mathbf{B e}$ & $<0.310$ & 1.22 \\
\hline $\mathbf{N i}$ & 10.3 & 11 \\
\hline $\mathbf{T l}$ & $<0.252$ & 0.20 \\
\hline- & - & $\mathbf{m g} / \mathbf{k g})$ \\
\hline benzene & $<0.25$ & 10 \\
\hline phenol & $<1$ & 5.2 \\
\hline cyanide (total) & $\mathrm{NM}$ & 1.2 \\
\hline cyanide (amenable) & $\mathrm{NM}$ & 0.86 \\
\hline
\end{tabular}

NM - Not Measured

a SCHWMR R.61-79.261.24(b) "Characteristic of Toxicity."

b SCHWMR R.61-79.268.48 "Universal Treatment Standards."

Table 2. Customer Recommended Values for Preparation of TCLP Sample

\begin{tabular}{|c|c|}
\hline Parameter & $\mathbf{4 Q 0 8}$ \\
\hline Water-to-Premix ratio & $0.59^{*}$ \\
\hline (Daratard 17) gal/Ton premix & 0.26 \\
\hline (Clean Air 100) gal/Ton premix & 0.20 \\
\hline
\end{tabular}

* Targeted 0.60. Actual value used in Shielded Cells. 


\subsection{Saltstone Testing}

Saltstone testing was performed by B\&WTSG-RACL and GEL Laboratories, LLC. Activities associated with the 4QCY08 saltstone samples were:

\section{At B\&WTSG-RACL,}

- performing the TCLP extraction,

- digesting the TCLP leachate, and

- analyzing the digested leachate.

At GEL

- $\quad$ performing extractions on solid subsamples shipped from B\&WTSG-RACL and

- analyzing extracts.

\subsubsection{B\&WTSG-RACL}

The samples arrived at B\&WTSG-RACL, Lynchburg, Virginia on February 12, 2009 for analysis. Shipping container temperatures were documented to be within specifications. The samples were delivered with proper chain of custody documentation and signatures. All sample containers arrived without any visible signs of tampering or breakage.

The Metals method 6020A analysis was performed on an X-7 Series Inductively Coupled Plasma - Mass Spectrometer (ICP-MS). The instrument measures ions produced by a radio-frequency inductively coupled plasma. Analyte species originating in a liquid are nebulized and the resulting aerosol transported by argon gas into the plasma torch. The ions produced by high temperatures are entrained in the plasma gas and introduced, by means of an interface, into a mass spectrometer. The ions produced in the plasma are sorted according to their mass-to-charge ratios and quantified with a channel electron multiplier. Mass interferences must be assessed and valid corrections applied or the data flagged to indicate problems.

The Metals method 7470A analysis was performed on a Leman PC 200 II instrument which consists of a cold vapor atomic absorption spectrometer (CVAA) set to detect mercury at a wavelength of $253.7 \mathrm{~nm}$. The mercury is reduced to the elemental state and aerated from solution in a closed system. The mercury vapor passes through a cell positioned in the light path of an atomic absorption spectrophotometer. Absorbance (peak height) is measured as a function of mercury concentration.

A portion of the leachate from the fourth quarter sample was used as the quality control sample (matrix spike) for the ICP-MS and CVAA.

\subsubsection{GEL Laboratories, LLC}

The subsamples arrived at GEL Laboratories, LLC, Charleston, South Carolina on February 19, 2009 for analysis. Shipping container temperatures were documented to be within specifications. The samples were delivered with proper chain of custody documentation and signatures. All sample containers arrived without any visible signs of tampering or breakage.

The method 8260B analysis was performed with an HP6890/HP5973 gas chromatograph/mass spectrometer using a Restek RTX-Volatiles column.

The methods 9012A and 9066 were performed using a Lachat QuickChem FIA+ 8000 Series. 


\subsection{Results \& Discussion}

\subsection{Sample Results}

Results were summarized in Table 3 from the data package for these analyses. ${ }^{6}$ Data is presented in these results as reported by the vendors.

\subsubsection{B\&WTSG-RACL}

Analytes detected but at concentrations too low to determine quantitatively have been flagged with the "B" qualifier. Analytes that were not detected have been flagged with the "U" qualifier. In addition to the results, Detection Limits (DLs) have been given. The DL is the minimum concentration of an analyte that can be identified, measured, and reported with $99 \%$ confidence that the concentration is above zero. The DL values given in the table are the results from this study adjusted for sample dilution. The Quantitation Limit (QL) is the lowest level at which an analyte may be accurately and reproducibly quantitated.

Results in Table 3, when compared with the DLs and QLs, can be organized into three groups:

- Beryllium was not detected in the leachate.

- Antimony, cadmium, chromium, silver, nickel, and thallium were detected below the QLs.

- Arsenic, barium, lead, mercury, and selenium, were detected in the leachates at concentrations above the QLs.

Table 3. TCLP Leachates RCRA Metal Concentrations, DLs, and QLs

\begin{tabular}{|c||c||c||c||c||}
\hline \hline- & Methods & $\begin{array}{c}\text { Sample } \\
\text { Limits } \\
(\mu \mathrm{g} / \mathbf{L})\end{array}$ & $\begin{array}{c}\text { Sample } \\
\text { Limits } \\
(\mu \mathrm{g} / \mathbf{L})\end{array}$ & $\begin{array}{c}\text { Sample } \\
\text { Results } \\
(\mu \mathrm{g} / \mathbf{L})\end{array}$ \\
\hline SRS ID & - & - & - & $\mathbf{4 Q 0 8}$ \\
\hline B\&W ID & - & $\mathbf{D L}$ & $\mathbf{Q L}$ & $\mathbf{0 9 0 2 0 0 8 - 0 1}$ \\
\hline $\mathbf{S b}$ & $3015 \mathrm{~A}, 6020 \mathrm{~A}$ & 0.13 & 11.1 & ${ }^{\mathrm{B}} 3.8$ \\
\hline $\mathbf{A s}$ & $3015 \mathrm{~A}, 6020 \mathrm{~A}$ & 0.10 & 5.56 & 16.2 \\
\hline $\mathbf{B a}$ & $3015 \mathrm{~A}, 6020 \mathrm{~A}$ & 0.44 & 55.5 & 164 \\
\hline $\mathbf{C d}$ & $3015 \mathrm{~A}, 6020 \mathrm{~A}$ & 0.11 & 5.56 & ${ }^{\mathrm{B}} 0.25$ \\
\hline $\mathbf{C r}$ & $3015 \mathrm{~A}, 6020 \mathrm{~A}$ & 0.31 & 11.1 & ${ }^{\mathrm{B}} 6.9$ \\
\hline $\mathbf{P b}$ & $3015 \mathrm{~A}, 6020 \mathrm{~A}$ & 0.48 & 5.56 & 7.4 \\
\hline $\mathbf{H g}$ & $7470 \mathrm{~A}$ & 0.07 & 0.2 & 0.7 \\
\hline $\mathbf{S e}$ & $3015 \mathrm{~A}, 6020 \mathrm{~A}$ & 0.24 & 27.8 & 29.1 \\
\hline $\mathbf{A g}$ & $3015 \mathrm{~A}, 6020 \mathrm{~A}$ & 0.06 & 5.56 & ${ }^{\mathrm{B}} 0.10$ \\
\hline $\mathbf{B e}$ & $3015 \mathrm{~A}, 6020 \mathrm{~A}$ & 0.16 & 5.56 & ${ }^{\mathrm{U}} 0.16$ \\
\hline $\mathbf{N i}$ & $3015 \mathrm{~A}, 6020 \mathrm{~A}$ & 1.6 & 5.56 & ${ }^{\mathrm{B}} 3.6$ \\
\hline $\mathbf{T l}$ & $3015 \mathrm{~A}, 6020 \mathrm{~A}$ & 0.21 & 5.56 & ${ }^{\mathrm{B}} 1.2$ \\
\hline
\end{tabular}

- Indicates a location in the table for which an entry would not be appropriate.

${ }^{\mathrm{U}}$ Final concentration of the analyte was found to be below the DL.

${ }^{B}$ Analyte is present at a concentration above the DL but less than the QL.

\subsubsection{Comparison of Results to Regulatory Limits}

Results from the TCLP leachate analyses from Table 3 are replicated in Table 4 -with units changed from $\mu \mathrm{g} / \mathrm{L}$ to $\mathrm{mg} / \mathrm{L}$ - along with the regulatory limits that may be applied to the Saltstone waste form. Table 4 includes the SCHWMR R.61-79.261.24(b) limits above which a waste is to be considered characteristically hazardous for toxicity and the SCHWMR R.61-79.268.48 Universal Treatment 
Standards (UTS) for hazardous constituents. In addition, Maximum Contaminant Levels (MCLs) from the State Primary Drinking Water Regulations ${ }^{*}$ also have been included in Table 4. By comparing the sample results and the regulatory limits in Table 4, the following conclusions can be made:

- The saltstone waste form was not characteristically hazardous for toxicity.

- The leachate metals concentrations were below the Nonwastewater Standard for all of the metals.

The MCL is the limit for a constituent in drinking water. The MCL is used to determine the class of landfill required. At 10x MCL, a Class 3 landfill is required. The SDF vaults are permitted as a Class 3 landfill.

- The leachate metals concentrations were below the MCLs for antimony, barium, cadmium, chromium, lead, mercury, silver, beryllium, and thallium. Nickel does not have an MCL value.

- Arsenic exceeded the MCL.

The TCLP leachate RCRA metal concentrations were well below the SCHWMR R.61-79.261.24(b) limits for characteristically hazardous toxic waste. Similarly, all results were less than the UTS Nonwastewater Standard. None of the analyses were greater than 10x the MCL.

Table 4. Saltstone TCLP Results and Corresponding Regulatory Limits.

\begin{tabular}{|c|c|c|c|c|}
\hline - & Sample Results (mg/L) & \multicolumn{3}{|c|}{ Regulatory Limits } \\
\hline SRS ID & $4 Q 08$ & Toxicity $^{\mathrm{a}}$ & UTS $^{\mathbf{b}}$ & $M C L^{\mathrm{c}}$ \\
\hline B\&W ID & 0902008-01 & $(\mathrm{mg} / \mathrm{L})$ & $\begin{array}{c}\text { Nonwastewater } \\
\text { Standard } \\
\text { (mg/L TCLP) }\end{array}$ & $(\mathrm{mg} / \mathrm{L})$ \\
\hline $\mathbf{S b}$ & B $3.8 \mathrm{E}-03$ & - & 1.15 & 0.006 \\
\hline As & $1.62 \mathrm{E}-02$ & 5 & 5 & 0.010 \\
\hline $\mathbf{B a}$ & 0.164 & 100 & 21 & 2 \\
\hline Cd & ${ }^{\mathrm{B}} 2.5 \mathrm{E}-04$ & 1 & 0.11 & 0.005 \\
\hline $\mathrm{Cr}$ & ${ }^{\mathrm{B}} 6.9 \mathrm{E}-03$ & 5 & 0.6 & 0.1 \\
\hline $\mathbf{P b}$ & 7.4E-03 & 5 & 0.75 & $0.015^{\mathrm{d}}$ \\
\hline Hg & $7.0 \mathrm{E}-04$ & 0.2 & 0.025 & 2E-03 \\
\hline Se & 2.91E-02 & 1 & 5.7 & 0.05 \\
\hline Ag & ${ }^{\mathrm{B}} 1.0 \mathrm{E}-04$ & 5 & 0.14 & $0.1^{\mathrm{e}}$ \\
\hline $\mathbf{B e}$ & ${ }^{\mathrm{U}} 1.6 \mathrm{E}-04$ & - & 1.22 & 4E-03 \\
\hline $\mathbf{N i}$ & $3.6 \mathrm{E}-03$ & - & 11 & - \\
\hline $\mathrm{Tl}$ & ${ }^{\mathrm{B}} 1.2 \mathrm{E}-03$ & - & 0.20 & $2 \mathrm{E}-03$ \\
\hline
\end{tabular}

- Indicates a location in the table for which an entry would not be appropriate.

${ }^{\mathrm{U}}$ Final concentration of the analyte was found to be below the DL.

${ }^{\mathrm{B}}$ Analyte is present at a concentration above the DL but less than the QL.

a R.61-79.261.24(b) "Characteristic of Toxicity."

${ }^{\mathrm{b}}$ R.61-79.268.48 "Universal Treatment Standards."

${ }^{c}$ SCDHEC State Primary Drinking Water Regulation Maximum Contaminant Levels.

${ }^{\mathrm{d}}$ Lead action level from SCDHEC 61-58.11.B.

${ }^{\mathrm{e}}$ Secondary drinking water parameter.

\footnotetext{
${ }^{*}$ Regulations 61-58 through 61-58.15 are promulgated pursuant to S.C. Code Sections 44-55-10 et seq. and are collectively known as the State Primary Drinking Water Regulations.
} 


\subsubsection{Quality Assurance}

The following subsections include summaries of results from blanks, laboratory control samples, matrix spikes, and matrix spike duplicates. The data package for this task also includes data for calibration verifications, interference checks, and serial dilutions.

\subsubsection{Blanks}

Blank concentrations are given in Table 5. In the TCLP Blank, lead levels were above the QL. Arsenic, barium, cadmium, chromium, silver, beryllium, nickel, and thallium were present at levels above their DLs, but below their QLs. Mercury was not detected. The analytical laboratory reports non-detectable values as the DL.

Table 5. TCLP Blank.

\begin{tabular}{|c||c||}
\hline Analyte & TCLP Blank $(\mu \mathrm{g} / \mathrm{L})$ \\
\hline $\mathbf{S b}$ & ${ }^{\mathrm{B}} 2.7$ \\
\hline $\mathbf{A s}$ & ${ }^{\mathrm{B}} 2.8$ \\
\hline $\mathbf{B a}$ & ${ }^{\mathrm{B}} 5.2$ \\
\hline $\mathbf{C d}$ & ${ }^{\mathrm{B}} 0.24$ \\
\hline $\mathbf{C r}$ & ${ }^{\mathrm{B}} 2.3$ \\
\hline $\mathbf{P b}$ & 9.0 \\
\hline $\mathbf{H g}$ & ${ }^{\mathrm{U}} 0.07$ \\
\hline $\mathbf{S e}$ & ${ }^{\mathrm{B}} 5.6$ \\
\hline $\mathbf{A g}$ & ${ }^{\mathrm{B}} 0.41$ \\
\hline $\mathbf{B e}$ & ${ }^{\mathrm{B}} 0.17$ \\
\hline $\mathbf{N i}$ & ${ }^{\mathrm{B}} 2.8$ \\
\hline $\mathbf{T l}$ & ${ }^{\mathrm{B}} 2.8$ \\
\hline
\end{tabular}

${ }^{\mathrm{B}}$ Analyte is present at a concentration above the DL but less than the QL.

${ }^{\mathrm{U}}$ Analyte is present at a concentration below the DL.

\subsubsection{Laboratory Control Samples}

Results from the Laboratory Control Sample (LCS) are given in Table 6. The LCS post spike recoveries met USEPA SW-846 acceptance limits for all elements except Sb which was 67 percent. Laboratory Control Samples are clean aqueous solutions analyzed to assure integrity of the analytical technique exclusive of matrix effects. 
Table 6. RCRA Metal Laboratory Control Sample

\begin{tabular}{||c||c|c||c||}
\hline \hline Analyte & Laboratory Control $(\boldsymbol{\mu g} / \mathbf{L})$ & Recovery (\%) \\
\hline- & True & Measured & $70-130$ \\
\hline \hline $\mathbf{S b}$ & 875.0 & 589.4 & 67 \\
\hline $\mathbf{A s}$ & 755.0 & 655.0 & 87 \\
\hline $\mathbf{B a}$ & 2180.0 & 2021.1 & 93 \\
\hline $\mathbf{C d}$ & 112.0 & 105.1 & 94 \\
\hline $\mathbf{C r}$ & 417.0 & 396.7 & 95 \\
\hline $\mathbf{P b}$ & 1630.0 & 1537.2 & 94 \\
\hline $\mathbf{H g}$ & 8.4 & 8.1 & 96 \\
\hline $\mathbf{S e}$ & 502.0 & 399.1 & 80 \\
\hline $\mathbf{A g}$ & 574.0 & 543.2 & 95 \\
\hline $\mathbf{B e}$ & 629.0 & 559.4 & 89 \\
\hline $\mathbf{N i}$ & 843.0 & 791.1 & 94 \\
\hline $\mathbf{T l}$ & 445.0 & 402.1 & 90 \\
\hline
\end{tabular}

\subsubsection{Matrix Spikes}

Results from analysis of the matrix spike (MS) and matrix spike duplicates (MSD) are given in Table 7. The initial concentrations in the first column are reproduced from Table 3. These results show that:

- The percent recoveries (\%R) obtained from the MS analyses met the recommended quality control acceptance criteria for percent recoveries for all applicable analytes.

- The percent recoveries (\%R) obtained from the MSD analyses met the recommended quality control acceptance criteria for percent recoveries for all applicable analytes.

- The RPD(s) between the MS and MSD met the acceptance limits. 
Table 7. TCLP Leachates RCRA Metal Matrix Spike and Duplicate Results

\begin{tabular}{|c|c|c|c|c|c|c|c|}
\hline \multirow{2}{*}{$\begin{array}{c}\text { Analyte } \\
-\end{array}$} & \multicolumn{2}{|c|}{$\begin{array}{c}\text { Initial Concentrations } \\
(\mu \mathrm{g} / \mathrm{L})\end{array}$} & \multicolumn{2}{|c|}{$\begin{array}{l}\text { Spiked Sample } \\
(\mu \mathrm{g} / \mathrm{L})\end{array}$} & \multicolumn{2}{|c|}{ Recovery (\%) } & \multirow{2}{*}{$\begin{array}{l}\text { RPD } \\
(\%)\end{array}$} \\
\hline & $\begin{array}{l}\text { BWXT ID } \\
\text { 0902008-01 }\end{array}$ & $\begin{array}{l}\text { Spike } \\
\text { Added }\end{array}$ & Spike & $\begin{array}{c}\text { Spike } \\
\text { Duplicate }\end{array}$ & Spike & $\begin{array}{c}\text { Spike } \\
\text { Duplicate }\end{array}$ & \\
\hline Sb & $\mathrm{B}_{3.8}$ & 556 & 486 & 485 & 87 & 87 & 0 \\
\hline As & 16.2 & 2222 & 1964 & 1955 & 88 & 87 & 0 \\
\hline $\mathbf{B a}$ & 164 & 2222 & 2142 & 2137 & 90 & 90 & 0 \\
\hline Cd & ${ }^{\mathrm{B}} 0.25$ & 55.6 & 44.4 & 45.2 & 80 & 81 & 2 \\
\hline $\mathrm{Cr}$ & B 6.9 & 222 & 188 & 190 & 82 & 83 & 1 \\
\hline $\mathbf{P b}$ & 7.4 & 556 & 525 & 529 & 93 & 94 & 1 \\
\hline $\mathrm{Hg}$ & 0.7 & 5.00 & 5.37 & 5.55 & 93.3 & 96.9 & 3 \\
\hline Se & 29.1 & 2222 & 1838 & 1844 & 82 & 82 & 0 \\
\hline Ag & ${ }^{\mathrm{B}} 0.10$ & 55.6 & 43.9 & 43.1 & 79 & 77 & 2 \\
\hline $\mathrm{Be}$ & ${ }^{\mathrm{U}} 0.16$ & 55.6 & 42.7 & 43.6 & 77 & 78 & 2 \\
\hline $\mathrm{Ni}$ & ${ }^{\mathrm{B}} 3.6$ & 556 & 420 & 426 & 75 & 76 & 1 \\
\hline $\mathbf{T l}$ & $\mathrm{B} 1.2$ & 2222 & 1986 & 1989 & 89 & 89 & 0 \\
\hline
\end{tabular}

(a) Values are those reported by the vendor in Reference 6.

${ }^{\mathrm{U}}$ Final concentration of the analyte was found to be below the DL.

${ }^{\mathrm{B}}$ Analyte is present at a concentration above the DL but less than the QL.

\subsubsection{Calibration Information}

- All initial calibration requirements have been met for this sample delivery group (SDG).

- All Contract Required Detection Limit standard(s) met the referenced advisory control limits.

- All interference check samples associated with this SDG met the established acceptance criteria.

- All continuing calibration blanks bracketing this batch met the established acceptance criteria.

- All continuing calibration verifications bracketing this SDG met the acceptance criteria.

\subsubsection{GEL Laboratories, LLC}

In addition to the results, Detection Limits (DLs) and Reporting Limits (RLs) have been given in Table 8. GEL reports general chemistry analyses (phenol and cyanide), that are not detected, using a form which shows results that are $<$ MDL as "ND", while organics such as benzene that are not detected are reported at the limit of quantitation - the reporting limit. Analytes detected but at concentrations too low to determine quantitatively have been flagged with the "J" qualifier. Analytes that were not detected have been flagged with the "U" qualifier. The DL is the minimum concentration of an analyte that can be identified, measured, and reported with $99 \%$ confidence that the concentration is above zero. The DL values presented in Table 8 are the results from this study adjusted for sample dilution. The RL is the lowest level at which an analyte may be accurately and reproducibly quantitated. Analytes with a positive blank result and detected in the sample above the DL have been flagged with the "V" qualifier. For phenol and cyanide, the designation "ND" is used when the analyte concentration is not detected above the detection limit. 
Table 8. Totals Concentrations, DLs, and RLs.

\begin{tabular}{|c||c||c||c|c||}
\hline \multirow{2}{*}{-} & Methods & $\begin{array}{c}\text { Sample } \\
\text { Limits } \\
(\mu \mathrm{g} / \mathbf{k g})\end{array}$ & $\begin{array}{c}\text { Sample } \\
\text { Limits } \\
(\mu \mathrm{g} / \mathbf{k g})\end{array}$ & $\begin{array}{c}\text { Sample } \\
\text { Results } \\
(\mu \mathrm{g} / \mathbf{k g})\end{array}$ \\
\hline SRS ID & - & - & - & $\mathbf{4 Q 0 8}$ \\
\hline GEL ID & - & $\mathbf{D L}$ & $\mathbf{R L}$ & $\mathbf{2 2 4 8 5 3 3 0 1}$ \\
\hline \hline \multirow{2}{*}{\begin{tabular}{c} 
benzene \\
phenol \\
cyanide \\
(total) \\
cyanide \\
\cline { 2 - 5 } (amenable)
\end{tabular}} & $5030 \mathrm{~B}, 8260 \mathrm{~B}$ & 28.8 & 96.2 & $\mathrm{U}_{96.2}$ \\
\cline { 2 - 5 } & $9010 \mathrm{~B}, 9066$ & 70.8 & 236 & $\mathrm{U}_{\mathrm{ND}}$ \\
\hline \multirow{2}{*}{} & $9012 \mathrm{~A}$ & 66.4 & 246 & ${ }_{\mathrm{ND}}$ \\
\hline
\end{tabular}

- Indicates a location in the table for which an entry would not be appropriate.

${ }^{\mathrm{U}}$ Final concentration of the analyte was found to be below the DL.

\subsubsection{Comparison of Results to Regulatory Limits}

Results from the analyses from Table 8 are replicated in Table 9-with units changed from $\mu \mathrm{g} / \mathrm{kg}$ to $\mathrm{mg} / \mathrm{kg}$ - along with the regulatory limits that may be applied to the Saltstone waste form. Table 9 includes the SCHWMR R.61-79.268.48 Universal Treatment Standards (UTS) for hazardous constituents. By comparing the sample results and the regulatory limits in Table 9, it can be concluded that for all of the analytes, the concentrations were below the Nonwastewater Standard.

Table 9. Saltstone Totals Results and Corresponding Regulatory Limits.

\begin{tabular}{|c||c|c||}
\hline \multicolumn{1}{|c||}{} & $\begin{array}{c}\text { Sample } \\
\text { Results } \\
(\mathbf{m g} / \mathbf{k g})\end{array}$ & $\begin{array}{c}\text { Regulatory Limits } \\
(\mathbf{m g} / \mathbf{k g})\end{array}$ \\
\cline { 1 - 2 } SRS ID & $\mathbf{4 Q 0 8}$ & \multirow{2}{*}{ UTS $^{\mathbf{b}}$} \\
\hline GEL ID & $\mathbf{2 2 4 8 5 3 3 0 1}$ & \\
\hline benzene & ${ }^{\mathrm{U}} 0.1$ & 10 \\
\hline phenol & ${ }^{\mathrm{U}} \mathrm{ND}$ & 6.2 \\
\hline cyanide (total) & 3.79 & 590 \\
\hline cyanide (amenable) & ${ }^{\mathrm{U}} \mathrm{ND}$ & 30 \\
\hline
\end{tabular}

- Indicates a location in the table for which an entry would not be appropriate.

${ }^{\mathrm{U}}$ Final concentration of the analyte was found to be below the DL.

${ }^{\mathrm{b}}$ R.61-79.268.48 “Universal Treatment Standards”.

\subsubsection{Quality Assurance}

The following subsections include summaries of results from blanks, laboratory control samples, matrix spikes, and matrix spike duplicates. The data package for this task also includes data for calibration verifications, interference checks, and serial dilutions.

\subsubsection{Blanks}

Blank concentrations are given in Table 10. Target and non target analytes were detected in the Method Blank below the reporting limit. Amenable to chlorination cyanide is determined by subtracting the results determined in the chlorinated cyanide test from those determined in the total cyanide test. The Method Blanks analyzed with this Sample Delivery Group (SDG) met the acceptance criteria. 
SRNL-STI-2009-00286

Revision 0

Table 10. Method Blank.

\begin{tabular}{||c||c||}
\hline Analyte & $\begin{array}{c}\text { Method Blank } \\
(\mu \mathbf{~ g} / \mathbf{k g})\end{array}$ \\
\hline benzene & ${ }^{\mathrm{J}} 1.0^{*}$ \\
\hline phenol & ${ }^{\mathrm{J}} 182^{\dagger}$ \\
\hline cyanide (total) & $\mathrm{U}^{\mathrm{N} D}$ \\
\hline cyanide (amenable) & -- \\
\hline
\end{tabular}

- Indicates a location in the table for which an entry would not be appropriate.

ND - Not Detectable

${ }^{\mathrm{J}}$ Final concentration of the analyte was found to be $\geq \mathrm{DL}$ and $<\mathrm{RL}$.

*DL and RL of samples are 100x those of method blanks.

'Reported value is RL of the method blank.

${ }^{\mathrm{V}}$ Final concentration of the analyte and blank was found to be $\geq \mathrm{DL}$.

${ }^{\mathrm{U}}$ Final concentration of the analyte was found to be below the DL.

\subsubsection{Laboratory Control Samples}

Results from the Laboratory Control Sample (LCS) are given in Table 11. All LCS recoveries met the vendor laboratory acceptance limits. ${ }^{*}$ Laboratory Control Samples are clean aqueous solutions analyzed to assure integrity of the analytical technique exclusive of matrix effects.

Table 11. Laboratory Control Sample.

\begin{tabular}{|c|c|c|c|c|c|}
\hline Analyte & \multicolumn{3}{|c|}{$\begin{array}{c}\text { Laboratory Control } \\
(\mu \mathrm{g} / \mathrm{kg})\end{array}$} & \multirow{2}{*}{\multicolumn{2}{|c|}{$\begin{array}{c}\text { Recovery }(\%) \\
- \\
\end{array}$}} \\
\hline- & True & Me: & ured & & \\
\hline benzene & 50.0 & \multicolumn{2}{|c|}{44.9} & \multicolumn{2}{|c|}{90} \\
\hline phenol & 2500 & 2310 & 1870 & 92 & 75 \\
\hline cyanide (total) & 174000 & \multicolumn{2}{|c|}{143000} & \multicolumn{2}{|c|}{82} \\
\hline cyanide (amenable) & -- & \multicolumn{2}{|c|}{--} & \multicolumn{2}{|c|}{--} \\
\hline
\end{tabular}

\subsubsection{Matrix Spikes}

Total cyanide is the only method where a matrix spike would be applicable. The method for benzene used a post analysis spike. The result from analysis of the matrix spike (MS) is given in Table 12. These results show that the percent recoveries (\%R) obtained from the MS analyses met the recommended quality control acceptance criteria for percent recoveries.

\footnotetext{
${ }^{*}$ USEPA SW-846 methods use a range of $70-130 \%$ for default limits until the laboratory establishes their own limits based on the recoveries they normally achieve for spiked compounds.
} 
SRNL-STI-2009-00286

Revision 0

Table 12. Matrix Spike Results.

\begin{tabular}{|c||c|c|c|c||}
\hline \multirow{2}{*}{ Analyte } & \multicolumn{2}{|c|}{$\begin{array}{c}\text { Initial Concentrations } \\
(\boldsymbol{\mu g} / \mathbf{k g})\end{array}$} & \multirow{2}{*}{$\begin{array}{c}\text { Spiked Sample } \\
(\boldsymbol{\mu} \mathbf{g} / \mathbf{k g})\end{array}$} & Recovery (\%) \\
\hline \multirow{2}{*}{ benzene } & $\begin{array}{c}\text { GEL ID } \\
\mathbf{2 2 1 0 9 2 0 0 1}\end{array}$ & $\begin{array}{c}\text { Spike } \\
\text { Added }\end{array}$ & & \\
\cline { 2 - 3 } & ${ }^{\mathrm{U} N D}$ & 50 & 49.2 & 98 \\
\hline \hline \multirow{2}{*}{$\begin{array}{c}\text { cyanide } \\
\text { (total) }\end{array}$} & ${ }^{\mathrm{U} N D}$ & 50 & 46.8 & 94 \\
\cline { 2 - 3 } & ${ }^{\mathrm{U}} \mathrm{ND}$ & 5170 & 4680 & 92 \\
\hline
\end{tabular}

ND - Not Detectable

${ }^{\mathrm{U}}$ Final concentration of the analyte was found to be below the DL.

3.1.2.6 Calibration Information

- All initial calibration requirements have been met for this sample delivery group (SDG).

- All Contract Required Detection Limit standard(s) met the referenced advisory control limits.

- All interference check samples associated with this SDG met the established acceptance criteria.

- All continuing calibration blanks bracketing this batch met the established acceptance criteria.

- All continuing calibration verifications bracketing this SDG met the acceptance criteria. 


\subsection{Conclusions}

Preparation of the 4QCY08 saltstone samples and the subsequent TCLP analyses showed that:

- The saltstone waste form disposed of in the Saltstone Disposal Facility in 4QCY08 was not characteristically hazardous for toxicity.

- The concentrations of the eight RCRA metals and UHCs identified as possible in the saltstone waste form were present at levels below the UTS.

- Analyses met all quality assurance specifications of USEPA SW-846.

The saltstone waste form placed in the Saltstone Disposal Facility in 4QCY08 met the SCHWMR R.6179.261.24(b) RCRA metals requirements for a nonhazardous waste form. The TCLP leachate concentrations were less than 5x the MCLs in SCDHEC Regulations R.61-107.16, Subpart A, 16.5.

The saltstone waste form placed in the Saltstone Disposal Facility in 4QCY08 met the R.61-79.268.48(a) non wastewater treatment standards.

Analyses met all USEPA SW-846 quality assurance requirements. This included limits on holding times, laboratory control sample recoveries, matrix spike recoveries, serial dilution results when applicable, calibration verification, and interference checks. 


\subsection{References}

1. $\quad$ Liner, K.R., "Saltstone Grout Sampling (U)," ESH-EPG-2004-00318.

2. "Toxicity Characteristic Leaching Procedure," EPA SW-846, Procedure 1311.

3. Britt, T.E., "Assessment of Regulated Organics under 40 CFR Part 268, Section 48, Universal Treatment Standards, Relative to SRS Tank Farm Waste," LWO-LWE-2007-00052.

4. Bibler, N.E., DiPrete, C.C., "Results for the Fourth Quarter 2008 Tank 50 WAC Slurry Sample: Chemical Contaminant Results," SRNS-TR-2009-00144 Revision 0.

5. Liner, K.R., 11/28/2007, Private Communication.

6. Cozzi, A.D., "Data Package from Vendor for 4QCY08 TCLP Analysis," SRNL-L3100-200900091. 